\title{
Ethnic differences in the distribution of congenital malformations
}

\author{
P. B. TERRY \\ F.R.C.S.E., M.R.C.O.G. \\ R. G. CONDIE \\ M.D., M.R.C.O.G.
}

\author{
P. M. MATHEW \\ M.D., M.R.C.P.
}

J. G. BISSENDEN

M.B., M.R.C.P.

\section{Dudley Road Hospital, Birmingham B18 $7 Q H$}

\begin{abstract}
Summary
Major lethal and non-lethal congenital malformations occurring in babies born in Dudley Road Hospital in 1979,1980 and 1981 were related to the ethnic group of the mother. There was an increased incidence of gastrointestinal malformations in the Indian group and an increased incidence of abnormalities that could be associated with consanguinity and increased maternal age in the Pakistani group.

A sample population (2000 mothers) was obtained in the first 7 months of 1982 to determine the maternal age distribution and consanguinity rates in the various ethnic groups.
\end{abstract}

KEY WORDS: congenital malformations, blacks, whites, Asians.

\section{Introduction}

Congenital malformations are a major cause of perinatal mortality and morbidity. Antenatal diagnosis by the increased use of ultrasound (Campbell, 1976), plasma $\alpha$-feto protein (Brock et al., 1978) and amniocentesis in those mothers at increased risk should reduce the incidence of such malformations. However, the success of such techniques depends on the health education programmes and early booking. Many members of the ethnic minority groups book late (Condie and Terry, 1980) and, because of cultural and communication difficulties, are not amenable to health education.

In addition, there may be a genetic predisposition to certain malformations. Cultural influences, such as increased maternal age and a greater incidence of consanguinal marriages in those belonging to the Islamic religion, may have a considerable effect.

Dudley Road Hospital serves a multi-racial, innercity population. Over a 3-year period (1979-81), the major congenital malformations that occurred in the various ethnic groups were classified into broad categories. To determine the distribution of maternal age and the incidence of consanguinal marriages, a sample population (2000) who delivered in the first 7 months of 1982 were studied in greater detail.

\section{Patients and methods}

The ethnic origin of all mothers who delivered in 1979-81 was obtained from the Labour Ward delivery records. The case notes of the mothers who had congenitally malformed stillbirths and the infants who had major congenital malformations were studied in detail. The type of malformation was classified on the basis of the system used in the British Perinatal Mortality Survey (1963) into multiple, chromosomal, central nervous system, cardiovascular system, alimentary system, genitourinary system and 'other' malformations. Recognized syndromes were included in the multiple abnormality group unless they involved only one system. There were no major skeletal malformations.

The first $\mathbf{2 0 0 0}$ mothers who delivered in 1982 were interviewed, where necessary with the help of an interpreter, to determine the maternal age and any consanguinity. Marriage was classified into first cousin, distant and unrelated marriages.

\section{Results}

The Indian group had the highest congenital abnormality rate at $14 \cdot 2 / 1000$ (difference from the European group, $P<0.05$, Table 1) with a low incidence of consanguinous marriages and a low incidence of increased maternal age (Table 2).

The Pakistani group, also had a high rate at $12 \cdot 2 / 1000$ (difference from the European group, not significant, Table 1) had a high rate of consanguinity (55\% first cousin marriages) and a high incidence of older mothers (14\% over 35 years of age, Table 2 ). 
TABLE 1. Ethnic distribution and congenital abnormalities

\begin{tabular}{|c|c|c|c|c|c|c|c|c|c|}
\hline Ethnic group & $\begin{array}{c}\text { Total } \\
\text { mothers }\end{array}$ & $\begin{array}{c}\text { Total } \\
\text { congenital } \\
\text { abnormalities } \\
(\text { rate } / 1000)\end{array}$ & Multiple & Chromosomal & $\begin{array}{c}\text { Central } \\
\text { nervous } \\
\text { system }\end{array}$ & Cardiovascular & Alimentary & Genitourinary & Other \\
\hline Indian & 3241 & $46(14 \cdot 2)^{*}$ & 9 & 2 & 10 & 2 & $18 \ddagger$ & 4 & 1 \\
\hline Pakistani & 1635 & $20(12 \cdot 2)$ & $9 \dagger$ & $4 \dagger$ & 2 & 2 & 1 & 2 & 0 \\
\hline Bangladeshi & 311 & $2(6.4)$ & 0 & 2 & 0 & 0 & 0 & 0 & 0 \\
\hline West Indian & 1282 & $6(4 \cdot 7)$ & 0 & 1 & 1 & 1 & 3 & 0 & 0 \\
\hline European & 5035 & $43 \quad(8.5)$ & 8 & 5 & 13 & 5 & 6 & 6 & 0 \\
\hline Others & 169 & $0 \quad(0.0)$ & 0 & 0 & 0 & 0 & 0 & 0 & 0 \\
\hline Total & 11673 & $117(10 \cdot 0)$ & 26 & 14 & 26 & 10 & 28 & 12 & 1 \\
\hline
\end{tabular}

Difference from European group: ${ }^{*} P<0.05 ; \dagger P<0.01$ (multiple and chromosomal combined); $\ddagger P<0.001$.

TABLE 2. Ethnic distribution, consanguinity rates and incidence of increased maternal age

\begin{tabular}{|c|c|c|c|c|c|c|}
\hline \multirow[b]{2}{*}{ Ethnic Group } & \multirow[b]{2}{*}{$\begin{array}{c}\text { Total } \\
\text { mothers }\end{array}$} & \multicolumn{3}{|c|}{ Consanguinity $(\%)$} & \multicolumn{2}{|c|}{$\begin{array}{c}\text { Maternal } \\
\text { age }(\%)\end{array}$} \\
\hline & & $\begin{array}{l}\text { First } \\
\text { cousin }\end{array}$ & Distant & $\begin{array}{c}\text { Not } \\
\text { related }\end{array}$ & $>35$ & $>40$ \\
\hline Indian & 486 & 2 & 1 & 97 & 4 & 0 \\
\hline Pakistani & 314 & 55 & 24 & 21 & 14 & 6 \\
\hline Bangladeshi & 78 & 23 & 3 & 74 & 27 & 19 \\
\hline West Indian & 291 & 0 & 0 & 100 & 4 & 2 \\
\hline European & 769 & 0 & 0 & 100 & 5 & 1 \\
\hline
\end{tabular}

The distribution of the various types of congenital abnormalities was similar in the Indian and European group except for the much greater incidence of alimentary abnormalities in the Indians (difference from the Europeans, $P<0.001$, Table 1). The Pakistani group had a higher incidence of multiple and chromosomal abnormalities (difference from the European group, $P<0.01$, Table 1).

\section{Discussion}

The higher incidence of congenital abnormalities, largely accounted for by an increased incidence of alimentary malformations, in the Indian group cannot be explained on the basis of increased maternal age or higher consanguinity rates. Possible influences include environmental factors, such as diet (Bissenden et al., 1981), or a genetic predisposition to such abnormalities. The increased incidence of multiple and chromosomal malformations in the Pakistani group may be attributed to the increased maternal age and consanguinity.

This study, as with others performed at Dudley Road Hospital (Terry, Condie and Settatree, 1980; Terry and Condie, 1981), shows an increased incidence of perinatal pathology in the Indian group. The reason for this finding is not obvious. This study has also confirmed that, by using yet another perinatal epidemiological parameter, namely the distribution of congenital abnormalities, the Indian group differed from the Pakistani group makingôtis term 'Asian' when used to describe all mothers 年任 the Indian subcontinent, inappropriate.

\section{Acknowledgments}

We wish to thank Mrs S. Taunque, interpreter. Mr. P. B. Terryồ in receipt of a West Midland Regional Health Authority researh grant.

\section{References}

Bissenden, J.G., ScotT, P.H., King, J., Hallum, J., Mansfielì H.N. \& WhaRTON, B.A. (1981) Anthropometric and biochemicel changes during pregnancy in Asian and European mothers having light for gestational age babies. British Journal of Obstetrics afid Gynaecology, 88, 999.

British Perinatal MORTALITy SURVey (1963) Perinatal mortalig. (Eds. N.R. Butler and D.G. Bonham) E. \& S. Livingstong, Edinburgh and London.

Brock, D.J.H., SCRImgeour, J.B., Steven, J., Barron, L. \& WATT, M. (1978) Maternal plasma alpha-fetoprotein screening frer fetal neural tube defects. British Journal of Obstetrics asd Gynaecology, 85, 575.

CAMPBELL, S. (1976) Early detection of neural tube defects ultrasound. British Journal of Obstetrics and Gynaecology, 83, 330 .

CONDIE, R.G. \& TERRY, P.B. (1980) Factors affecting antenatal aff postnatal care. In: Health care of Asians (Eds P. Wilkinson, FS. Sharif \& C.D. O'Leary). Birmingham Area Health Authorfty (Teaching) Health Education Service.

TERRY, P.B. \& CONDIE, R.G. (1981) Ethnic differences in perinatal mortality. Postgraduate Medical Journal, 57, 790.

TERRY, P.B., Condie, R.G. \& SETtaTREe, R.S. (1980) Analysis ethnic differences in perinatal statistics. British Medical Journal, 281, 1307. 